Jurnal ISLAMIKA, Vol. 3, No. 2 (2020): 57-67

\title{
Performa Guru Dalam Manajemen Kelas
}

\author{
Deprizon \\ Universitas Muhammadiyah Riau \\ Email: deprizon@umri.ac.id
}

\begin{abstract}
This study examines and explores "teacher performance in the classroom management process". Leadership in learning requires an attractive performance, because the rights and responsibilities carried out and their views towards students are full of compassion, tenderness, this attitude should be part of the value of a teacher's dedication. The author tries to describe the teacher's performance in the classroom management process in educational institutions, namely: (1) describing the policies and educational foundations in the form of classroom and outside learning planning. (2) applying learning components as a system in the teaching and learning process. (3) communicating in professional, social communities and facilitating community learning. (4) managing the class with appropriate approaches and procedures that are relevant to the characteristics of students. (5) researching, developing and innovating in the field of education and learning, and being able to use the results for professional development. This research methodology refers to the library approach (qualitative descriptive library research). This study focuses on the object of study in the form of written theoretical sources. The results of this research, especially for the academic world, can be used as a reference and reference (literature) that can add to the library's treasury, especially in the scientific clusters of Islamic education.
\end{abstract}

Keywords: Performance, Teacher, Class Management.

\begin{abstract}
Abstrak
Penelitian ini mengkaji dan mendalami tentang "performa guru dalam proses manajemen kelas". Kepemimpinan dalam pembelajaran diperlukan performa yang menarik, karena hak dan tanggung jawab yang dilakukan serta pandangannya terhadap siswa penuh dengan kasih sayang, lemah lembut, maka Sikap inilah yang seharusnya menjadi bagian dari nilai dedikasi seorang guru. Penulis mencoba untuk memaparkan performa guru dalam proses manajemen kelas pada lembaga pendidikan, yaitu : (1) menjabarkan kebijakan dan landasan pendidikan dalam wujud perencanaan pembelajaran dikelas dan diluar kelas. (2) mengaplikasikan komponen-komponen pembelajaran sebagai suatu sistem dalam proses belajar mengajar. (3) melakukan komunikasi dalam komunitas profesi, social dan memfasilitasi pembelajaran masyarakat. (4) mengelola kelas dengan pendekatan dan prosedur yang tepat dan relevan dengan karakteristik peserta didik. (5) meneliti, mengembangkan, dan berinovasi dibidang pendidikan dan pembelajaran, dan mampu
\end{abstract}


memanfaatkan hasilnya untuk pengembangan profesi. Metodologi Penelitian ini mengacu kepada pendekatan kepustakaan (library research yang bersifat deskriptif Kualitatif). Penelitian ini memfokuskan objek kajiannya berupa sumber-sumber teoritis yang bersifat tertulis. Hasil dari penelitian ini terutama bagi dunia Akademis dapat dijadikan sebagai bahan acuan dan rujukan (literatur) yang dapat menambah khazanah pustaka terutama dalam rumpun ilmu bidang pendidikan Islam.

\section{PENDAHULUAN}

Guru dalam era milenial peran guru menjadi begitu kompleks, yang tentunya menuntut tingkat profesionalitas yang tinggi dalam melakukan proses pembelajaran. Ini disebabkan karena sekolah menjadi tempat untuk menyiapkan kemampuan peserta didik yang memadai sesuai dengan kapasitas intelektualnya. Dalam buku SPTK-21 (Depdiknas, 2002) tugas utama guru antara lain, yaitu : (1) menjabarkan kebijakan dan landasan pendidikan dalam wujud perencanaan pembelajaran dikelas dan diluar kelas. (2) mengaplikasikan komponen-komponen pembelajaran sebagai suatu sistem dalam proses belajar mengajar. (3) melakukan komunikasi dalam komunitas profesi, social dan memfasilitasi pembelajaran masyarakat. (4) mengelola kelas dengan pendekatan dan prosedur yang tepat dan relevan dengan karakteristik peserta didik. (5) meneliti, mengembangkan, dan berinovasi dibidang pendidikan dan pembelajaran, dan mampu memanfaatkan hasilnya untuk pengembangan profesi.

Unnruh dan Alexander mengungkapkan peran guru yang semakin kompleks meliputi ; (1) melakukan diagnosis ; mampu menganalisis kondisi yang mempengaruhi pembelajaran siswa. (2) guru sebagai pembuat keputusan: terlibat dalam proses perencanaan dan pelaksanaan perubahan system sekolah, baik ditingkat local dan ataupun tingkat dinas. (3) guru yang cooperative : bekerjasama dengan siswa, staf dalam menyukseskan pembelajaran disekolah. (4) peran strategis berupa ketrlibatan dalam merencanakan dan mendesign perkembangan masing-masing siswa, membuat penilaian yang tepat, membuat perencanaan tentang sprektum kurikulum yang lebih luas. (5) guru sebagai manager: menyiapkan sumber daya dan keahlian untuk melancarkan pembelajaran siswa, termasuk bantuan staff atau asisten dan sebagainya. (6) guru sebagai fasilitator proses pembelajaran melalui dinamika kelompok, belajar mandiri, penelitian dan berbagai eksperimen bidang study. (7) guru sebagai pembimbing siswa untuk memotivasi kreatifitas, dengan rasa empati, penuh kehangatan dan saling mengerti. (8) guru sebagai evaluator.

Lebih jauh dari itu bahwa menjelaskan tentang tiga peran pembelajaran yang lebih luas sebagai pengambil keputusan dikelas, yang meliputi tugas pembelajaran, konseling dan pengelolaan. Disamping itu ada tiga fungsi guru, yaitu merencanakan, melaksanakan dan mengevaluasi merupakan fungsi yang harus dijalankan dalam rangka mewujudkan proses pemvelajaran dikelas. Keinginan untuk memberikan fungsi yang lebih luas kepada guru adalah untuk memberikan tingkat otonomi yang tinggi dalam memimpin proses belajar mengajar dikelas sehingga guru dapat membina anak dengan tingkat ketergantungan yang rendah terhadap guru. (Fasli Jalal, 2001;9) 
John Goodled melakukan penelitian dengan publikasi pendidikan "Behind The Classroom Door", menemukan bahwa kualitas pembelajaran akan sangat ditentukan oleh guru, manakala guru sudah memasuki ruang kelas serta pintu kelas tertutup maka kehidupan kelas akan menjadi wewenang dan tanggung jawab seorang guru. Guru merupakan sosok penting yang akan mewarnai suasana kehidupan didalam kelas. Apakah guru mampu untuk memberikan dan membangun motivasi anak untuk berprestasi atau tidak? disinilah guru diharapkan dapat membangun komunikasi yang efektif dalam rangka menciptakan hubungan interaktif antara guru dan siswa dikelas. Sehingga tuntutan guru profesional menjadi sangat penting untuk meningkatkan kualitas pembelajaran disekolah.

\section{METODOLOGI}

\section{BAGAN METODOLOGI PENELITIAN PERFORMA GURU DALAM PROSES MANAJEMEN KELAS}

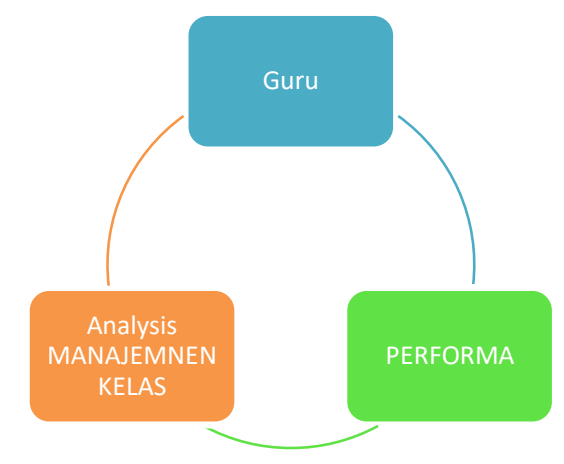

\section{HASIL PENELITIAN}

\section{A. Performa guru (sebagai pemimpin).}

Kepemimpinan mempunyai peran yang penting karena kepemimpinan (Leadership) merupakan inti dari manajemen, karena kepemimpinan merupakan motor penggerak bagi sumber-sumber dan alat-alat manusia dalam suatu organisasi. Hasil tinjauan terhadap penulis lain menggungkapkan bahwa para penulis manajemen umumnya sepakat bahwa kepemimpinan adalah proses mempengaruhi aktivitas seseorang atau sekelompok orang untuk mencapai tujuan dalam situasi tertentu.(Supian, 2005; 179).

Konsep kepemimpinan dalam suatu organisasi. Menurut Hicks adalah sebagai pengaruh terhadap staf, sebagai pembimbing dan menyeimbangkan antar pencapaian tujuan anggota atau invidu, dengan tujuan organisasi secara keseluruhan. Tanpa pemimpin, suatu organisasi hanya akan merupakan campur aduk antara manusia dan peralatan. seorang pemimpin harus memiliki pengetahuan dan pendidikan yang luas. Karena, Pendidikan merupakan permasalahan besar yang menyangkut nasib dan masa depan bangsa dan Negara. Karena itu, tuntutan reformasi politik, ekonomi, sosial, hak azazi manusia, sistem pemerintahan dan agraria tidak akan membuahkan hasil yang baik tanpa reformasi sistem pendidikan. Krisis multidimensi yang melanda Negara dan bangsa 
Indonesia dewasa ini, tidak hanya disebabkan oleh krisis ekonomi, social dan politik, melainkan juga oleh krisis pada sistem pendidikan nasional.

Dengan demikian, pendidikan memegang peranan kunci dalam menyediakan sumber daya manusia yang berkualitas, bahkan sangat menentukan berhasil atau gagalnya pembangunan. secara lebih arif dapat disimpulkan bahwa pendidikan bermutu menghasilkan sumber daya manusia bermutu dan merupakan kata kunci dari keberhasilan pembangunan. atas dasar fenomenalogi bahwa pada sa'at ini, Indonesia menghadapi masalah yang sifatnya multidimensi yang menuntut pemecahan segera. Masyarakat yang mutu sumber daya manusianya rendah, cenderung tidak akan mampu memecahkan masalahnya. Berbeda dengan masyarakat yang mutu sumber daya manusia-nya tinggi, mereka memiliki potensi untuk memecahkan masalahnya. Serta mampu merumuskan pola pemberdayaan masyarakat untuk berpatisipasi aktif dalam meningkatkan kesejahteraan dan kualitas hidup. Dalam hal ini, apabila lembaga pendidikan tidak dikelola oleh para profesional, maka sumber daya manusia Indonesia di masa mendatang, terutama dalam era globalisasi akan menghadapi tantangan yang sangat berat. Akan tetapi jika dikelola secara profesional, maka masalah kualitas sumber daya manusia, akan dapat teratasi. (Sutikno, 2006; 1).

Ungkapan ini memperjelas bahwa kepemimpinan merupakan kecakapan untuk mempengaruhi dan meyakinkan orang-orang, agar dengan penuh semangat mengupayakan pencapaian tujuan organisasi melalui proses kerjasama. Hicks, menampilkan tiga macam gaya kepemimpinan yang utama yaitu otokrasi, demokrasi, dan liberal. Menurutnya dituntut kemepuan bagi seorang pemimpin untuk memilih gaya kepemimpinan yang tepat. Ketepatan tersebut sangat menentukan tingkat efektivitas pencapaian tujuan individu dan tujuan organisasi.

Sorang pemimpin yang baik adalah seorang pemimpin yang tidak melaksanakan sendiri tindakan-tindakan yang bersifat operasional, tetapi mengambil keputusan, menentukan kebijaksanaan dan menggerakkan orang lain untuk melaksanakan keputusan yang telah diambil sesuai dengan kebijaksanaan yang telah digariskan.

Manajer juga berfungsi untuk mengawasi kinerja yang dipimpinnya. Untuk lebih mendalam maka kepemimpinan terbagi beberapa bentuk: (1) Kepemimpinan yang Visioner; Kepemimpinan yang visioner diartikan oleh Thariq M. As-suwaida dengan visionary leadership yaitu pemimpin yang memiliki arah dan wujud masa depan yang jelas merupakan gambaran masa depan yang disepakati dengan rasa kebersamaan dan komitmen yang tinggi untuk mewujudkannya, (2) Kepemimpinan yang bertanggung jawab: Kepemimpinan yang bertanggung jawab adalah; a) mampu menunjukan caranya dan menentukan tujuan dan arah organisasi, b) mampu terus berada didepan dalam suatu hubungan spiritual dengan orang-orang anda, c) mampu membimbing orang melalui metode-metode dan arahan-arahan. (Thariq, 2006; 120), (3) Kepemimpinan Motivasi: Teori motivasi memperkenalkan imbalan sebagai salah satu alat untuk menstimulasi anggota organisasi, dalam upaya merubah perilakunya sebagai individu, kea rah perilaku 
yang diinginkan organisasi. Sehingga memungkinkan terciptany perilaku yang saling menguntungkan (secara timbal balik) antara organisasi dan anggota-anggotanya. Hal ini perlu didukung oleh system komunikasi dua arah yang penuh keterbukaan antara pemimpin dan bawahannya, (4) Kepemimpinan Sosial Learning; Kepemimpinan social learning terletak pada perilaku kepemimpinan, kelangsungan, dan interaksi timbale balik semua variable-variabel yang ada, (5) Kepemimpinan yang cakap dalam berkomunikasi; Kepemimpinan ini dapat diartikan sebagai potensi pemimpin untuk memamfaatkan sumber daya manusia yang dimiliki organisasi, bertujuan untuk pencapaian tujuan organisasi. (Miftah Toha, 2006; 46).

Dengan demikian, dari kesemua gaya kepemimpinan diatas merupakan sesuatu hal yang mutlak harus dimiliki oleh setiap person dari pemimpin itu sendiri. Karena, seorang pemimpin harus mempunyai karakteristik yang ideal terhadap organisasi yang dipimpinnya. Untuk itu diperlukan pengetahuan yang utama seorang pemimpin mengetahui situasional organisasinya yang mencakup internal maupun ekternal secara administrative. Mengingat peran guru dalam era milenial peran guru menjadi begitu kompleks, yang tentunya menuntut tingkat profesionalitas yang tinggi dalam melakukan proses pembelajaran termasuk penampilan atau ferforma seorang guru. (KBBI).

Sekolah menjadi tempat guru untuk menyiapkan kemampuan peserta didik yang memadai sesuai dengan kapasitas intelektualnya. Dalam buku SPTK-21 (Depdiknas, 2002) tugas utama guru antara lain, yaitu : (1) menjabarkan kebijakan dan landasan pendidikan dalam wujud perencanaan pembelajaran dikelas dan diluar kelas. (2) mengaplikasikan komponen-komponen pembelajaran sebagai suatu sistem dalam proses belajar mengajar. (3) melakukan komunikasi dalam komunitas profesi, social dan memfasilitasi pembelajaran masyarakat. (4) mengelola kelas dengan pendekatan dan prosedur yang tepat dan relevan dengan karakteristik peserta didik. (5) meneliti, mengembangkan, dan berinovasi dibidang pendidikan dan pembelajaran, dan mampu memanfaatkan hasilnya untuk pengembangan profesi.

Unnruh dan Alexander mengungkapkan peran guru yang semakin kompleks meliputi ; (1) melakukan diagnosis ; mampu menganalisis kondisi yang mempengaruhi pembelajaran siswa. (2) guru sebagai pembuat keputusan : terlibat dalam proses perencanaan dan pelaksanaan perubahan system sekolah, baik ditingkat local dan ataupun tingkat dinas. (3) guru yang cooperative : bekerjasama dengan siswa, staf dalam menyukseskan pembelajaran disekolah. (4) peran strategis berupa ketrlibatan dalam merencanakan dan mendesign perkembangan masing-masing siswa, membuat penilaian yang tepat, membuat perencanaan tentang sprektum kurikulum yang lebih luas. (5) guru sebagai manager : menyiapkan sumber daya dan keahlian untuk melancarkan pembelajaran siswa, termasuk bantuan staff atau asisten dan sebagainya. (6) guru sebagai fasilitator proses pembelajaran melalui dinamika kelompok, belajar mandiri, penelitian dan berbagai eksperimen bidang study. (7) guru sebagai pembimbing siswa untuk memotivasi kreatifitas, dengan rasa empati, penuh kehangatan dan saling mengerti. (8) guru sebagai evaluator. 
Lebih jauh dari itu bahwa menjelaskan tentang tiga peran pembelajaran yang lebih luas sebagai pengambil keputusan dikelas, yang meliputi tugas pembelajaran, konseling dan pengelolaan. Disamping itu ada tiga fungsi guru, yaitu merencanakan, melaksanakan dan mengevaluasi merupakan fungsi yang harus dijalankan dalam rangka mewujudkan proses pemvelajaran dikelas. Keinginan untuk memberikan fungsi yang lebih luas kepada guru adalah untuk memberikan tingkat otonomi yang tinggi dalam memimpin proses belajar mengajar dikelas sehingga guru dapat membina anak dengan tingkat ketergantungan yang rendah terhadap guru. (Fasli Jalal, 2001; 9)

John Goodled melakukan penelitian dengan publikasi pendidikan " Behind The Classroom Door", menemukan bahwa kualitas pembelajaran akan sangat ditentukan oleh guru, manakala guru sudah memasuki ruang kelas serta pintu kelas tertutup maka kehidupan kelas akan menjadi wewenang dan tanggung jawab seorang guru. Guru merupakan sosok penting yang akan mewarnai suasana kehidupan didalam kelas. Apakah guru mampu untuk memberikan dan membangun motivasi anak untuk berprestasi atau tidak? disinilah guru diharapkan dapat membangun komunikasi yang efektif dalam rangka menciptakan hubungan interaktif antara guru dan siswa dikelas. Sehingga tuntutan guru profesional menjadi sangat penting untuk meningkatkan kualitas pembelajaran disekolah.

Menurut Garys A Davis dan Margaret A Thomas bahwa guru professional mempunyai empat kemampuan yaitu pertama kemapuan yang terkait dengan iklim belajar dikelas meliputi ; 1) memiliki ketrampilan interpersonal, khusunya kemampuan untuk menunjukkan empati, penghargaan kepada siswa dan ketulusan 2) memiliki hubungan baik dengan siswa 3) mampu menerima, mengakui dan memperhatikan siswa secara tulus; 4) mampu menunjukkan minat dan antusias yang tinggi dalam mengajar; 5) mampu menciptakan atmosfer untuk tumbuhnya kerjasama dan kohesifitas antar dan dalam kelompok 6) mampu melibatkan siswa dalam mengorganisasi dan merencanakan pembelajaran; 7) mampu mendengarkan siswa dan menghargai hak siswa untuk berbicara dalam setiap diskusi; mampu meminimalkan friksi-friksi dikelas. Kedua, kemampuan yang terkait dengan strategi manajemen pembelajaran meliputi; 1) memiliki kemampuan untuk menangani siswa yang tidak mempunyai perhatian, suka menyela, mengalihkan pembicaraan, dan mampu memberikan transisi substansi bahan ajar dalam proses pembelajaran; 2) mampu bertanya atau memberikan tugas yang memerlukan tingkat berfikir yang berbeda untuk semua siswa 3) kemampuan yang terkati dengan umpan balik dan penguatan meliputi ; 1) mampu memberikan umpan balik yang positif atas respon siswa; 2) mampu memberikan respon yang bersifat membantu terhadap siswa yang lamban belajar 3)mampu memberikan tindak lanjut terhadap jawaban siswa yang kurang memuaskan; 4) mampu memberikan kemampuan yang terkait dengan peningkatan diri meliputi; 1) mampu menerapkan kurikulum dan metode mengajar secara inovatif 2) mampu memanfaatkan perencanaan guru secara kelompok untuk menciptakan dan mengembangkan metode pembelajaran yang relevan. Dalam Study Basic Education Quality bahwa guru professional mempunyai karakteristik meliputi; 1) kemampuan professional sebagai kemampuan intelegensia, sikap dan prestasi dibidang pekerjaan, 2) upaya professional sebagai upaya untuk menerapkan kemampuan professional dalam 
menerapkan kegiatan professional dalam proses belajar mengajar 3) waktu yang dicurahkan untuk kegiatan professional adalah intensitas waktu untuk mengajar, 4) akuntabilitas profesi manakala pekerjaan yang dilakukan dapat menjamin kesejahteraan hidupnya. (Masyuri, 2001; 15).

Posisi penting guru merupakan tanggung jawab profesi dan moril untuk meningkatkan upaya-upaya professional dalam memimpin pembelajaran di kelas. Guru hendaknya bersikap lebih demokratis di kelas. Kelas harus dikondisikan sebagai tempat untuk meningkatkan kemampuan intelegensia siswa. Guru dalam memimpin pembelajaran di kelas hendaknya mengarahkan perkembangan siswa secara maksimal, Guru hendaknya mampu untuk memotivasi siswa agar termotivasi untuk menguasai pengetahuan yang diberikan, memberikan motivasi untuk selalu meningkatkan prestasi belajar. Sejalan dengan upaya ini maka pengembangan pribadi siswa baik emosi dan intelektualnya hendaknya bagian penting yang menjadi perhatian seorang guru. Karena bagaimanapun seorang guru harus memperhatikan perbedaan kemampuan siswa menghadapi perkembangan intelektual dan emosional yang maksimal. tapi bagaimanapun upaya guru untuk meningkatkan prestasi siswa tanpa dukungan semua unsur yang ada di sekolah termasuk karyawan dan orang tua yang ada diluar sekolah, maka tidak akan mencapai hasil maksimal. Untuk itu disamping bekerjasama dengan siswa, guru juga dituntut untuk bekerjasama dengan staf sekolah lainnya dalam memberikan motivasi kepada siswa untuk mencapai prestasi siswa. Staff sekolah yang berupaya untuk memberikan bantuan-bantuan layanan dalam menunjang proses pembelajaran disekolah.

Hal ini tentunya tidak terlepasdari SDM guru. Berbicara persoalan sumber daya manusia (human resources), sesungguhnya mencakup dua bidang kajian, fisik dan non fisik, namun yang bersentuhan langsung dengan dunia pendidikan selalu dihubungkan dengan persoalan-persoalan yang berkenanaan dengan yang non fisik (aspek kecerdesan dan mental) seperti kemampuan berfikir, kemampuan berkereativitas, kemampuan menentukan keputusan, berbuat, dan lain sebagainya. Hal ini mengingat aspek yang pertama biasanya diupayakan melalui gerakan program kesehatan, gizi dan olah raga, kendatipun sesungguhnya upaya motivasi, latihan dan pembinaan ke arah ini pun tidak dapat dilepaskan begitu saja dari upaya pendidikan. Kesadaran untuk meningkatkan kualitas fisik pun memiliki korelasi dengan kualitas pendidikan yang diperolehnya. Pendekanya, baik kualitas fisik maupun non fisik manusia akan selalu memiliki hubungan yang signifikan dengan berbagai program pengembangan sumber daya manusia melalui upaya-upaya dunia pendidikan. (Muhmida Yeli, 2005; 125)

Bertitik tolak dari probema internal guru sebagai tenaga kependidikan, yang pernah dilansir oleh sebuah surat kabar terkemuka di Indonesia Kompas pada tanggal 20 November 2004 yang lalu, menuliskan antara lain "menurunnya kualitas guru, dan diskriminasi status guru" membuatkan kita gerah dan bertanya-tanya, apakah pekerjaan guru merupakan suatu profesi?, para ahli dan pakar pendidikan sudah lama menggolongkan pekerjaan itu suatu profesi, demikian juga banyak definisi tentang pekerjaan guru sebagai profesi. 
Pengertian profesi secara Umum. Rsulullah SAW pernah bersabda bahwa "sesuatu pekerjaan yang diserahkan kepada seseorang bukan profesinya, maka tunggulah kehancuran" (Hadist riwayat Bukhari). Kata profesi identik juga dengan kata keahlian, demikian juga Jarvis mengartikan seseorang yang melakukan tugas profesi juga sebagai seorang yang ahli (expert). Pada sisi lain profesi mempunyai pengertian seseorang yang menekuni pekerjaan berdasarkan keahlian, kemampuan, teknik, dan prosedur berlandaskan intelektualitas. Hal demikian dapat dibaca pula pendapat Volmer dan Mills, Mc Cully, dan Diana W. Kommers, mereka sama-sama mengartikan profesi sebagai spesialisasi dari jabatan intelektual yang diperoleh melalui studi dan training, bertujuan menciptakan keterampilan, pekerjaan yang bernilai tinggi, sehingga keterampilan dan pekerjaan itu diminati, disenangi oleh orang lain, dan dia dapat melakuakan pekerjaan itu dengan mendapatkan imbalan berupa bayaran, upah, dan gaji (Payment).

Namun profesi Guru, dipundak mereka dipikul beban dan tanggung jawab kependidikan yang besar, mencerdaskan kehidupan bangsa, merubah perilaku, dan moral anak didik. Guru mengembangkan tugas sebagaimana dinyatakan dalam Undang-Undang Sistem Pendidikan nasional (UUSPN) tahun 2003, dalam pasal 39 ayat 1 . tenaga kependidikan bertugas melaksanakan administrasi, pengelolaan, pemgembangan, pengawasan, dan pelayanan teknis untuk menunjang proses pendidikan pada satuan pendidikan. Ayat 2. pendidik merupakan tenaga professional yang bertugas merencanakan dan melaksanakan proses pembelajaran, melakukan pembimbingan dan pelatihan, serta melakukan penelitian dan pengapdian kepada masyarakat, terutama bagi pendidik pada perguruan tinggi. (Martinis Yamin, 2007; 1-2).

Dari berbagai pengertian profesi di atas menimbulkan makna, bahwa profesi yang disandang oleh tenaga kependidikan atau guru, adalah sesuatu pekerjaan yang membu tuhkan pengetahuan, keterampilan, kemampuan, keahlian, dan keteladanan untuk menciptakan anak untuk memiliki perilaku sesuai yang diharapkan.

Persoalan pendidikan saat ini memang di rasa sangatlah kompleks. Sujibto, Rektor Universitas Jakarta dalam sebuah laporan hasil penelitian menyebutkan kasus-kasus yang menyebabkan pendidikan nasional terpuruk diantaranya adalah: (1) Krisis nilai yang melanda peserta didik sehingga mereka mudah sekali untuk tawuran, (2) Kualitas pendidikan cenderung merosot, hal itu ditandai dengan Ujian Nasional yang menurun, (3) Angka Drop-out yang cukup tinggi, ketidak jujuran orang-orang yang terlibat dalam pendidikan mulai dari peserta didik yang nyontek dan senang senang tawuran, guru dan sampai dengan personalia di instansi lembaga pendidikan yang korup.

\section{B. Analysis manajemen Kelas}

Pelaksanaan (actuating) tidak lain merupakan upaya untuk menjadikan perencanaan menjadi kenyataan, dengan melalui berbagai pengarahan dan pemotivasian agar setiap guru dapat melaksanakan kegiatan secara optimal sesuai dengan peran, tugas dan tanggung jawabnya. Hal yang penting untuk diperhatikan dalam pelaksanan (actuating) ini adalah bahwa seorang guru akan termotivasi untuk mengerjakan sesuatu 
jika : (1) merasa yakin akan mampu mengerjakan, (2) yakin bahwa pekerjaan tersebut memberikan manfaat bagi dirinya, (3) tidak sedang dibebani oleh problem pribadi atau tugas lain yang lebih penting, atau mendesak, (4) tugas tersebut merupakan kepercayaan bagi yang bersangkutan dan (5) hubungan antar teman dalam organisasi tersebut harmonis.

Pada kesempatan lain, Prof. M. Dachnel Kamars (2005; 67) menyatakan bahwa banyak pakar tidak menjadikan pelaksanaan ini sebagai suatu fungsi dari sekian banyak fungsi manajemen. Tetapi Terry mengupas dan memasukkannya, istilah lain yang digunakan untuk fungsi ini ialah executing (pelaksanaan). terhadap proses pembelajaran tindakan kelas yang dilakukan adalah untuk melahirkan generasi yang memiliki pemahaman terhadap konsep pengetahuan dan konsep agama secara baik dan juga mampu bersaing dalam era globalisasi. melaksanakan proses pembelajaran yang efektif dan efisien adalah membentuk tim olah raga dan pramuka dalam melaksanakan pelayanan terhadap warga sekolah dan masyarakat secara arif dan bijak, supaya terciptanya lingkungan sekolah yang nyaman, sehat dan bersahabat.

Penulis yakin dan percaya, bahwa kualitas kepemimpinan akan terjaga. Apa bila pemimpinan (Ferporma guru) terampil memukau, karena hak dan tanggung jawabnya ia laksanakan, pandangannya terhadap siswanya penuh dengan kasih sayang, lemah lembut (komunikasi aktif). Sikap inilah yang seharusnya menjadi ruh dan urat nadi dari seorang guru di kelas dalam proses pembelajaran. tetapi tidak terlaksana dengan maksimal, akibat dari minimnya kemampuan dan wawasan para guru yang mengenyampingkan epistimologi dalam bidang keilmuan yang dimilikinya. Hal tersebut terjadi apa bila motivasi yang diberikan seorang guru sebagai pemimpin tidak di laksanakan oleh siswanya, maka semua yang di cita-citakan tidak akan tercapai.

\section{KESIMPULAN}

Mutu pendidikan pada lembaga pendidikan formal merupakan salah satu tolok ukur yang menentukan kemajuan suatu bangsa. dengan mencermati mutu pendidikan suatu bangsa atau negara, seseorang akan dapat memperkirakan peringkat negara tersebut di antara Negara-negara di dunia. Guru adalah salah satu komponen pendidikan yang memegang peran penting dalam keberhasilan pendidikan, guru diharapkan mampu memainkan yang ideal terutama ferformanya dalam prose pembelajaran. Salah satu cara meningkatkan mutu pendidikan adalah memperbaiki ferforma guru. Ferforma guru adalah penampilan guru ketika di dalam kelas yang penuh dengan kewibawaan tinggi, tanggung jawab, kejujuran dan kerjasama. Beberapa faktor yang mempengaruhi ferforma guru antara lain adalah kemampuan penguasaan kelas (Manajemen Kelas), kejujuran, kedisiplinan guru, dan pengembangan sumber daya guru (SDM).

Guru merupakan profesi, supaya guru menjadi profesional maka ia dituntut untuk berupaya semaksimal mungkin menjalankan profesinya berdasarkan keilmuannya. sebagai 
seorang guru profesional maka tugas guru sebagai pendidik, pengajar dan pelatih hendaknya dapat berimbas kepada siswanya. dalam hal ini guru hendaknya dapat meningkatkan terus kinerjanya yang merupakan modal bagi keberhasilan pendidikan.

\section{DAFTAR PUSTAKA}

Arikunto, Suharsimi. 2004. Dasar-dasar Supervisi. Jakarta: Rineka Cipta.

Banun Muslim, Sri. 2009. Supervisi Pendidikan Meningkatkan Kualitas Profesional Guru. Mataram: Alfabeta.

Departemen Agama RI. 1984. Petunjuk Pelaksanaan Tugas Pengawas Pendidikan Agama Islam. Jakarta: Departemen Agama RI.

Departemen Agama RI. 1995. Tuntunan Supervisi Pendidikan Agama Islam pada Madrasah Ibtidaiyah. Jakarta: Departemen Agama RI. Jarvis, Pounds. 1969. Instruksional Supervision. Boston: Allyn and Bacom, Inc. Kadim Masaong, Abdul. 2013. Supervisi Pembelajaran dan Pengembangan Kapasitas Guru Memberdayakan Pengawas sebagai Gurunya Guru. Bandung: Alfabeta. Maunah, Binti. 2009. Supervisi Pendidikan Islam, Teori dan Praktik. Yogyakarta: Sukses Offset.

Pidarta, Made. 2012. Pemikiran tentang Supervisi Pendidikan. Jakarta: Bumi Aksara. Piet A, Sahertian. 1981. Prinsip dan Tehnik Supervisi Pendidikan. Surabaya: Usaha Nasional.

Purwanto, M. Ngalim. 1983. Administrasi Pendidikan. Jakarta: Mutiara.

Rosdakarya. . 2008. Administrasi dan Supervisi Pendidikan. Bandung: Remaja

R.J Firth, Alfonso GR, R. F, Neville. 1981. Instruksional Supervision. Boston: Allyn and Bacom Inc.

Soetopo, Hendyat, Soemanto, Wasty. 1988. Kepemimpinan dan Supervisi Pendidikan. Jakarta: Bina Aksara.

Sutiasna, Oteng. 1987. Administrasi Pendidikan: Dasar Teoritis untuk Praktek Profesional. Jakarta: Mutiara.

https://kbbi.web.id/performa 
Jurnal ISLAMIKA, Vol. 3, No. 2 (2020): 57-67 